\title{
Comentario:
}

\section{EL MORALISMO RELIGIOSO GARANTIZADOR DEL ORDEN PÚBLICO}

\author{
João Roberto Barros ${ }^{1}$ \\ Eu não consigo amar \\ Quem náo enxerga a vida como eu vejo \\ Quem não entende a Bíblia como eu leio \\ Um outro Deus eu criei \\ Tấo cruel, a imagem do meu eu. \\ (Herege, Mauro Henrique)
}

Referência do artigo comentado: NAVARRO, P. P. Ordem e perigo: superfícies do corpo político. Trans/Form/Açáo: revista de filosofia da Unesp, v. 44, n. 1, p. 327-346, 2021.

En su texto Navarro (2021) subraya el vínculo entre las políticas neoliberales y el discurso religioso en la conformación del dispositivo de orden público. En las líneas que siguen, nos gustaría enfocar esta relación mediante los conceptos de poder pastoral y homo oeconomicus, más específicamente teniendo en cuenta lo ocurrido en Brasil.

\footnotetext{
${ }^{1}$ Docente na Universidade Federal da Integração Latino-Americana, Foz do Iguaçu, PR - Brasil. (D) https://orcid.org/0000-0003-0324-7079 E-mail: joao.barros@unila.edu.br

https://doi.org/10.1590/0101-3173.2021.v44n1.25.p347
} 
En Brasil, particularmente vemos una alianza entre el neoliberalismo y una ola evangélica. En 2010 los evangélicos eran más de 42 millones. Cerca de $25 \%$ de la población. En 2050 hay proyecciones de un crecimiento vertiginoso, alcanzando los 39,8\% y sobrepasando la comunidad católica (DINIZ, 2016). En cuanto a los temas de cuño moral, las diversas denominaciones que forman ese universo son en su mayoría de carácter conservador.

En tiempos actuales, llama la atención el miedo alimentado por sectores religiosos conservadores frente a la presencia de contra conductas por parte de los movimientos sociales. Cierta vez, conversando con un pastor, le dije, que desde mi punto de vista, los cristianos tenían dos miedos principales: 1) la exposición de sus hijos a contra conductas no heterosexuales en espacios públicos y contenidos de género en las escuelas; y 2) la obligación de las iglesias a realizar casamientos homosexuales mediante judicialización. En lo tocante al primero, mi interlocutor se puso de acuerdo, afianzando una impresión muy rudimentaria de todo un torbellino que tomaba la escena pública en el año de 2018.

Dicho diálogo va al encuentro de la afirmación de Pérez Navarro, al considerar la represión a cuerpos no heterosexuales como estrategia para la conformación del espacio público.

Nesse sentido, o espaço público seria também produzido mediante a determinação do que se considera uma perturbação inadmissível da ordem pública pronta para ser confinada na prisão ou, no caso, no espaço doméstico. Dito de outra forma, a produção do que chamamos espaço público depende da definiçáo prévia do que conta, e do que não conta, e do que náo conta, como um corpo apto para a coabitação. (NAVARRO, 2021, p. 332).

En 2018, en Brasil, durante el proceso electoral, vimos una dinámica semejante que conllevó a la "A Marcha da Família com Deus pela Liberdade" en 1964 (OPERAMUNDI, 2014). En ese entonces, muchos sectores conservadores usaran del discurso religioso para apoyar un cambio de gobierno y una ruptura en la democracia. El régimen militar que perduró por dos décadas tubo como frutos una extrema desigualdad y miles de muertos y desaparecidos. Durante dicho periodo, el uso de la violencia seguía siendo tolerado por los seguidores de Cristo. En su mutación más reciente, el poder pastoral una vez más corrobora al discurso del orden en "defensa de la familia". Aún en 2016 con la deposición de Dilma Roussef, esta expresión fue una de las 
más utilizadas por los congresistas que votaron en contra de la mandataria, ya que la amenaza comunista rodeaba la familia brasilera. Volviendo a lo sucedido en 2018, los defensores de la familia se importaban más en garantizar el orden y las buenas costumbres, que rechazar el uso de la violencia y discursos de intolerancia reproducidos por parte de muchos candidatos.

Podemos agregar también las palabras de Foucault cuando consideraba el interés público en Historia de la sexualidad $1^{2}$. Problematizando la incitación a la producción de discursos sobre el sexo, leemos:

Esta técnica [la confesión que anima el dispositivo de sexualidad] quizás habría quedado ligada al destino de la espiritualidad Cristiana, o a la economía de los placeres individuales, si no hubiese sido apoyada y reimpulsada por otros mecanismos. Esencialmente, presenta un "interés público". (FOUCAULT, 1976, p. 33; 2010, p. 25). ${ }^{3}$

Sabemos que los conceptos de población y poder pastoral fueron trabajados por Foucault de modo más extenso en Seguridad, Territorio, Población. No obstante, ya en HS1 encontramos una mención al término población relacionándolo al sexo. "El sexo no es cosa que sólo se juzgue, es cosa que se administra. Participa del poder público; exige procedimientos de gestión [...]. En el corazón de este problema económico y político de la población se encuentra el sexo". (FOUCAULT, 1976, p. 35-36; 2010, p. 2728).

Sumando al debate la problematización sobre el neoliberalismo, Foucault nos recuerda: "La competencia es un principio de orden en el dominio de la economía de mercado", aún que, moral y sociológicamente, sea un principio más disolvente que unificador (FOUCAULT, 2004a, p. 248; 2012, p. 279). Todavía, nos advierte Foucault, a los neoliberales de nuestros tiempos no les basta insertar el modelo empresa al cuerpo social. Hace falta también moldear las subjetividades en el sentido de convertir todos y todas en células de producción eminentemente concurrenciales.

Aquí vemos un enlace fundamental para comprender nuestros tiempos: el poder pastoral ${ }^{4}$, algo tan longevo y al mismo tiempo aparentemente incólume, tiene una función subjetivante dentro del marco neoliberal. $\mathrm{Su}$

\footnotetext{
2 De aquí en adelante, referido como HS1.

3 Todas las citas a Foucault están compuestas por el original seguido de la traducción.

${ }^{4}$ Remitimos humildemente a nuestro trabajo Poder pastoral e cuidado de si em Foucault (2020).
} 
actuación posibilita la formación de una subjetividad que alía las características del homo oeconomicus, conforme caracterizado por Foucault, a un discurso religioso. Enlace difícil pero extremadamente pertinente.

Al poder pastoral brasilero, defensor del orden, importa menos que el modelo neoliberal profundice la transformación del trabajador en una "máquina-competencias" asociada a una "elección moral", tal cual nos advierte Lazzarato (2011, p. 32), que la compasión y la justicia practicada en los evangelios. Más allá de que dicha moralidad le lleve al endeudamiento y éste represente una herramienta de gobierno sobre la vida de las personas. Desde esa mirada, la asociación entre poder pastoral y neoliberalismo viabiliza la producción del homo oeconomicus que asocia la reducción de los riesgos a la condición económica de las personas y sus cuerpos castos (LAZZARATO, 2015, p. 173).

En esa perspectiva, para los más conservadores, el espacio público no puede abrigar cuerpos de placer. Todo lo contrario. Se hace necesario que el modelo empresa esté asociado a un cuerpo casto, que tiene sus anhelos direccionados a la competencia, la adquisición de bienes y al éxito económico. Mal saben ellos que, en un contexto tan distinto a lo descrito por Webber, ya no se puede sostener una supuesta elección divina para justificar el uso de la violencia o la búsqueda por riquezas materiales. Nuestros días claman por respeto a la diversidad y la dignidad humana, no importando el credo, color o la opción de género.

\section{REFERENCIAS}

BARROS II, J. R. Poder pastoral e cuidado de si em Foucault. Foz do Iguaçu: EDUNILA, 2020.

DINIZ, J. A transição religiosa no Brasil: 1872-2050. Humanitas UNISINOS, 2016. Disponible en: http://www.ihu.unisinos.br/noticias/558131-a-transicao-religiosa-nobrasil-1872-2050-. Acceso en: 25 ene 2021.

FOUCAULT, M. Histoire de la sexualité I: la volonté de savoir. Paris: Gallimard, 1976.

FOUCAULT, M. Naissance de la biopolitique. Cours au Collège de France 1978-1979. Paris: Gallimard, 2004a.

FOUCAULT, M. Sécurité, Territoire, Population. Cours au Collège de France 19771978. Paris: Gallimard, 2004b. 
FOUCAULT, M. Seguridad, Territorio, Población. Curso en el Collège de France 1977-1978. Trad. Horacio Pons. Buenos Aires: Fondo de Cultura Económica, 2007.

FOUCAULT, M. Historia de la sexualidad 1: la voluntá de saber. Trad. Ulises Guińazú. Buenos Aires: Siglo Veintiuno, 2010.

FOUCAULT, M. Nacimento de la biopolítica. Curso en el Collège de France 19781979. Trad. Horacio Pons. Buenos Aires: Fondo de Cultura Económica, 2012.

LAZZARATO, M. O governo das desigualdades: crítica da insegurança neoliberal. Trad. Renato Abramowics Santos. São Carlos: EdUFSCAR, 2011.

LAZZARATO, M. Governing by Debt. Trans. Joshua D. Jordan. South Pasadena: Semiotext(e), 2015.

NAVARRO, P. P. Ordem e perigo: superfícies do corpo político. Trans/Form/Açáo: revista de filosofia da Unesp, v. 44, n. 1, p. 327-346, 2021.

OPERAMUNDI. Golpe de 64: 'Marcha da Família com Deus pela Liberdade' completa 50 anos; saiba quem a financiou e dirigiu. 2014. Disponible en: https://operamundi. uol.com.br/politica-e-economia/34445/golpe-de-64-marcha-da-familia-com-deus-pelaliberdade-completa-50-anos-saiba-quem-a-financiou-e-dirigiu . Acceso en: 25 enero 2021.

Recebido: 10/10/2020

Aceito: $13 / 10 / 2020$ 
BARROS, J. R. 